\title{
TRABALHO ESCRAVO CONTEMPORÂNEO: A EXPLORAÇÃO DOS BOLIVIANOS NAS INDÚSTRIAS TEXTÊIS E CONFECÇÕES DE SÃO PAULO
}

DIEGO FERREIRA AVELLAR RIOS

Graduando em Direito, modalidade Integral, pela Escola Superior Dom Helder Câmara. E-mail: avellardiego@gmail.com.

\section{CAIO AUGUSTO SOUZA LARA}

Mestre e Doutor em Direito pela Faculdade de Direito da Universidade Federal de Minas Gerais - UFMG. Professor da Escola Superior Dom Helder Câmara. Pesquisador Associado ao Programa RECAJ-UFMG - Acesso à Justiça e Solução de Conflitos. Secretário de Comunicação do Conselho Nacional de Pesquisa e Pósgraduação em Direito - CONPEDI. Belo Horizonte-MG. E-mail: caiolarabh@yahoo.com.br

\section{RESUMO}

O tema-problema da pesquisa que se pretende desenvolver é sobre a exploração dos bolivianos nas indústrias têxteis e confecções do Estado de São Paulo. A Bolívia é um dos países com um dos piores IDH entre os países sulamericanos e, por isso, muitos bolivianos deixam o seu local de origem em busca de melhores condições de vida, por meio de ofertas de emprego, geralmente enganosas. Nesse sentido, é válido ressaltar em quais condições tais imigrantes chegam no Brasil: geralmente estão no país de maneira ilegal, sem laços sociais, sem recursos financeiros, com desconhecimento da língua e com desorientação espacial. Nos locais de trabalho estão sujeitos à péssimas condições de infraestrutura, com uma longa jornada e um recebimento ínfimo sobre as peças produzidas, o que agravava ainda 


\section{Personalidade Acadêmica Homenageada:}

Raymundo Juliano Feitosa (Universidade Federal do Rio Grande do Norte - UFRN)

mais as dívidas que foram adquiridas nos custos da viagem e serão estabelecidas nas relações entre empregador e empregado nos casos em que o tipo de escravidão é por dívida-comum com os bolivianos. $\mathrm{O}$ trabalho em condições análogas à escravidão deve ser entendido a partir do princípio da dignidade humana, o qual se configura como uma das características basilares do Estado Democrático de Direito. A legislação brasileira trata dessa questão no artigo 149 do Código Penal, de acordo com a Lei no10.803/2003 e segundo a OIT e o Conselho de Direitos Humanos das Nações Unidas o conceito de escravidão estabelecido pelo Brasil é apoiado, pois trata-se de um princípio amplo. Desde 2010 até 2018, 38 grifes e varejistas foram responsabilizadas por trabalho escravo segundo a ONG Repórter Brasil. O problema objeto da investigação científica proposta é: quais os fatores que fundamentam a existência do trabalho escravo com os imigrantes bolivianos e as correspondentes violações de direitos no setor da indústria têxtil e confecções de São Paulo? A partir das reflexões preliminares sobre o tema, é possível afirmar inicialmente que os motivos que levam uma grande quantidade de imigrantes bolivianos estarem submetidos ao trabalho escravo nas indústrias têxteis de São Paulo baseiam-se na busca por melhores condições de vida em países vizinhos. Tais imigrantes não tem conhecimento da lei trabalhista local e enfrentam uma imensa dificuldade de adquirir emprego. Tendo em vista esses pontos que os resultam a uma situação de vulnerabilidade, facilita-se a sua exploração por parte dos empregadores. O objetivo geral do trabalho é analisar a situação de vulnerabilidade dos imigrantes bolivianos no que se refere à sua exploração nas indústrias do ramo têxtil e nas confecções de São Paulo. A pesquisa que se propõe pertence à vertente metodológica jurídicosociológica. No tocante ao tipo de investigação, foi escolhido, na classificação de Witker (1985) e Gustin (2010), o tipo jurídico-projetivo. O raciocínio desenvolvido na pesquisa será predominantemente dialético. De acordo com a técnica de análise de conteúdo, afirma-se que se trata de uma pesquisa teórica, o que será possível a partir da análise de conteúdo dos textos doutrinários, normas e demais dados colhidos na pesquisa. A partir do exposto, conclui-se preliminarmente que é inaceitável a transformação de seres humanos em meras "mercadorias" na escravidão moderna 
Personalidade Acadêmica Homenageada:

Raymundo Juliano Feitosa (Universidade Federal do Rio Grande do Norte - UFRN)

no século XXI. A escravidão foi abolida no Brasil, já tardiamente no contexto mundial, em 1888. A legislação trata do caso e, mesmo assim, grandes e pequenas empresas cometem tais delitos que conferem um atentado à dignidade da pessoa humana. Além disso, é válido ressaltar iniciativas que levam à sociedade a conscientização sobre o referido cenário. Dentro desse raciocínio destaca-se o surgimento de organizações não governamentais tal como a Repórter Brasil, especializada na área de comunicação e projetos sociais, além da iniciativa do Ministério do Trabalho de incluir empresas envolvidas no emprego de trabalho escravo em uma "lista suja".

PALAVRAS-CHAVE: Escravidão Contemporânea; Imigrantes Bolivianos; Indústria Têxtil; Dignidade Humana.

\section{REFERÊNCIAS}

AS MARCAS da moda. Repórter Brasil - 12 jul. 2012. Disponível em: https://reporterbrasil.org.br/2012/07/especial-flagrantes-de-trabalho-escravo-naindustria-textil-no-brasil. Acesso em: 15 abr. 2019.

BRASIL. Lei no 10.803, de 11 de dezembro de 2003. Altera o art. 149 do Decreto-Lei № 2.848, de 7 de dezembro de 1940 - Código Penal, para estabelecer penas ao crime nele tipificado e indicar as hipóteses em que se configura condição análoga à de escravo. Brasília, DF: Presidência da República. Disponível em: http://www.planalto.gov.br/ccivil_03/LEIS/2003/L10.803.htm. Acesso em: 07 maio. 2019.

COM AMISSIMA, são 38 as marcas. Repórter Brasil - 21 dez. 2018. Disponível em: https://reporterbrasil.org.br/2018/12/com-amissima-sao-38-as-marcas-de-modaenvolvidas-com-trabalho-escravo-no-brasil/. Acesso em: 20 abr. 2019.

GUSTIN, Miracy Barbosa de Sousa; DIAS, Maria Tereza Fonseca. (Re)pensando a pesquisa jurídica: teoria e prática. 3ª . ed. Belo Horizonte: Del Rey, 2010.

MIRAGLIA, Lívia Mendes Moreira. Trabalho Escravo Contemporâneo: conceituação à luz do princípio da dignidade da pessoa humana. 2008. Dissertação (Mestrado em Direito) - Pontifícia Universidade Católica de Minas Gerais, Belo Horizonte, 2008.2 Disponível em: http://portal.pucminas.br/imagedb/documento/DOC_DSC_NOME_ARQUI201602171 02425-n.pdf. Acesso em: 16 abr. 2019. 
Personalidade Acadêmica Homenageada:

Raymundo Juliano Feitosa (Universidade Federal do Rio Grande do Norte - UFRN)

O TRABALHO escravo na indústria da moda. Belo Horizonte: UFMG, 24 abr. 2019. Clínica Trabalho Escravo e Tráfico de Pessoas. Disponível em: https://www.youtube.com/watch?v=EGsrugilgHk.

SUZUKI, Natália. Bolivianos em cortiços? Onde e como vivem os imigrantes submetidos ao trabalho escravo na cidade de São Paulo. In: FIGUEIRA, Ricardo Rezende; PRADO, Adonia Antunes; GALVÃO, Edna Maria. Discussões contemporâneas sobre o trabalho escravo: Teoria e pesquisa. Rio de Janeiro: Mauad X, 2016. Disponível em: http://escravonempensar.org.br/wpcontent/uploads/2018/05/natalia_suzuki_gptec-2.pdf. Acesso em: 16 abr. 2019.

TREVISAM, Elisaide; BARROSA FILHO, José. Ações e medidas visando a erradicação do trabalho escravo no Brasil Contemporâneo. Revista Jurídica Unicuritiba -. ISSN 2316-753x. v.02, n.43, p. 292-316. 2016. Disponível em: http://revista.unicuritiba.edu.br/index.php/RevJur/article/view/1833/1208. Acesso em: 20 maio. 2019.

WITKER, Jorge. Como elaborar una tesis en derecho: pautas metodológicas y técnicas para el estudiante o investigador del derecho. Madrid: Civitas, 1985. 